\title{
Technical and Practical Valuation of Hydrokinetic Turbine Integration into Existing Canal Infrastructure in South Africa: A Case Study ${ }^{\dagger}$
}

\author{
Chantel Niebuhr ${ }^{1, *}$, Marco van Dijk ${ }^{1}$ and Jay Bhagwan ${ }^{2}$ \\ 1 Department of Civil Engineering, University of Pretoria, Pretoria 0002, South Africa; \\ Marco.vandijk@up.ac.za \\ 2 Water Research Commission, Pretoria 0002, South Africa; Jayb@wrc.org.za \\ * Correspondence: chantel.niebuhr@up.ac.za; Tel.: +27-79-427-5190 \\ + Presented at the 3rd EWaS International Conference on "Insights on the Water-Energy-Food Nexus", \\ Lefkada Island, Greece, 27-30 June 2018.
}

Published: 30 July 2018

\begin{abstract}
Small-scale hydrokinetic (HK) energy systems is a renewable energy source which has never before been explored in South Africa, mainly due to the abundance of low-cost coal-powered electricity. A HK pilot project was implemented in an applicable section on the Boegoeberg irrigation canal in the Northern Cape Province of South Africa and tested for optimum functionality and correct application. This paper describes the HK system development and evaluates the technical viability and resilience of the system. Furthermore, the sustainability of such an installation into existing infrastructure in a developing country is analyzed.
\end{abstract}

Keywords: hydrokinetic energy; canal infrastructure; grid-integration; small-scale hydropower

\section{Introduction}

The demand for energy in South Africa (SA) is increasing whilst the availability of fossil fuels such as coal is decreasing. According to environmental statistics South Africa is among the top 20 countries with the highest level of carbon dioxide emissions, also being the highest emitter of GHGs in Africa due to the current fossil-fuel powered economy [1]. In 2010 the South African National Department of Minerals and Energy (DME) released an Integrated Resource Plan (IRP) to increase renewable energy sources to 17.8 Gigawatts by 2030 [2]. This allows a large opportunity for the development of renewable energy such as biomass, wind, solar and hydropower.

Hydropower is a trusted technology with significant potential in South Africa [3]. It is a form of clean renewable and sustainable energy making use of the available flow or head in water without consuming or polluting the water itself. Often these systems have long lifespans and high efficiencies with low operating costs [4]. Hydrokinetic (HK) systems are defined as in-flow turbines which are placed in the flow of water thus harnessing the kinetic energy of flowing water, or hydroelectric energy, to produce electricity [5]. In SA the Department of Water and Sanitation (DWS) asset management database revealed a total of 47 schemes with a network of more than $6500 \mathrm{~km}$ 's of canals. This reveals the extent of available potential for HK installations in canal systems. The canal systems include around 21,286 structures such as tunnels, syphons, weirs, control gates, chutes and drops exist, which also hold a large unexploited hydropower potential.

To showcase this potential and test the applicability and practicality of HK installation in South African canal systems a test installation was constructed in a representative canal section in SA. The implementation followed the process of appropriate site selection and installation of the HK device 
together with all components required for a functioning system within the South African legal and regulatory framework and current economic state.

\section{Site Description}

This study entailed the identification of sites with small-scale HK potential in a specific municipality, selected by governmental funding allocation. The site selection was thus limited to sections of the Boegoeberg irrigation canal in the !Kheis Municipality. The focus of the study was on developing a system with a generating capacity of less than $50 \mathrm{~kW}$ to aid the local municipality and prove success of such an installation. The site selection procedure followed the guidelines portrayed in Figure 1.
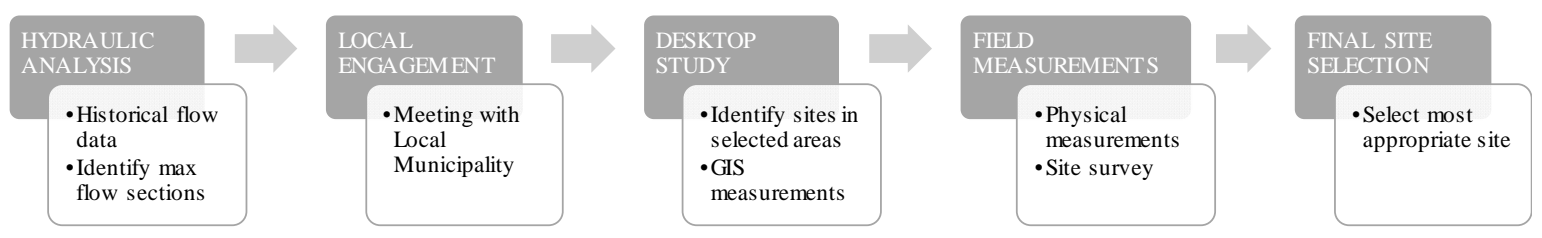

Figure 1. Site selection procedure.

A site adjacent to a water treatment works (WTW) in the town of Groblershoop, which lies in close proximity to an upper section of the canal was selected for installation. As shown in Figure 2 the canal section selected for installation is a combination of two straight sections, for final installation a total of 4 turbines will be placed in these sections which will feed a control system connected to the WTW. The WTW facility consists of a package treatment plant and two pump stations. Pump room 1 has 2 pumps with a usage of approximately $7.5 \mathrm{~kW}$ each, a stand-alone solar plant (Figure 3) supplies one of these pumps with off-grid electricity. Pump room 2 consists of 4 pumps each with a usage of $2.5 \mathrm{~kW}$ resulting in a total of $25 \mathrm{~kW}$ usage when operating at full capacity.

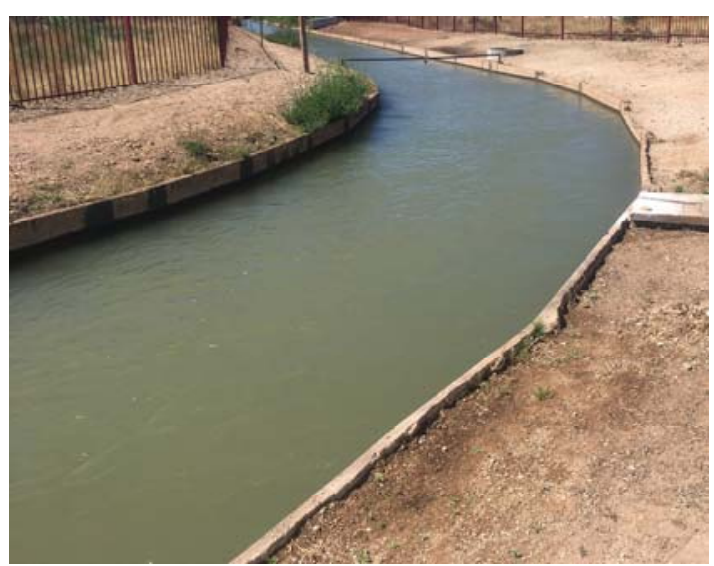

(a)

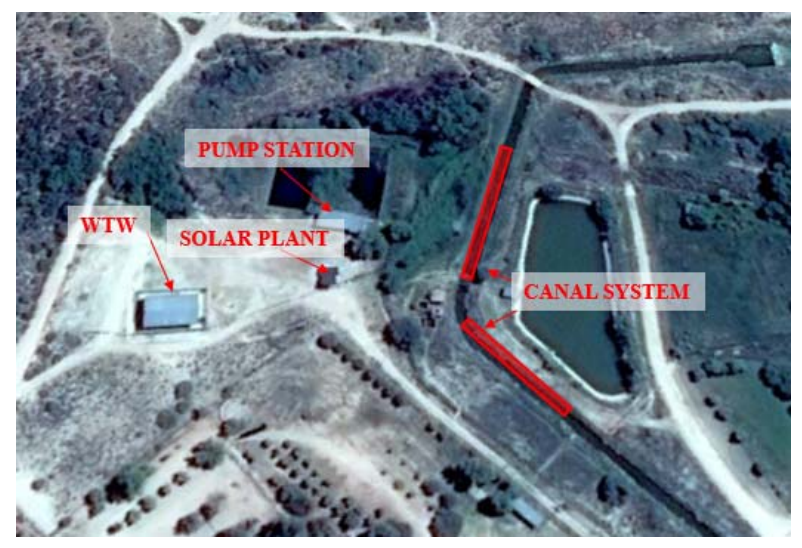

(b)

Figure 2. Typical canal testing site. (a) canal bend view (b) canal layout. 


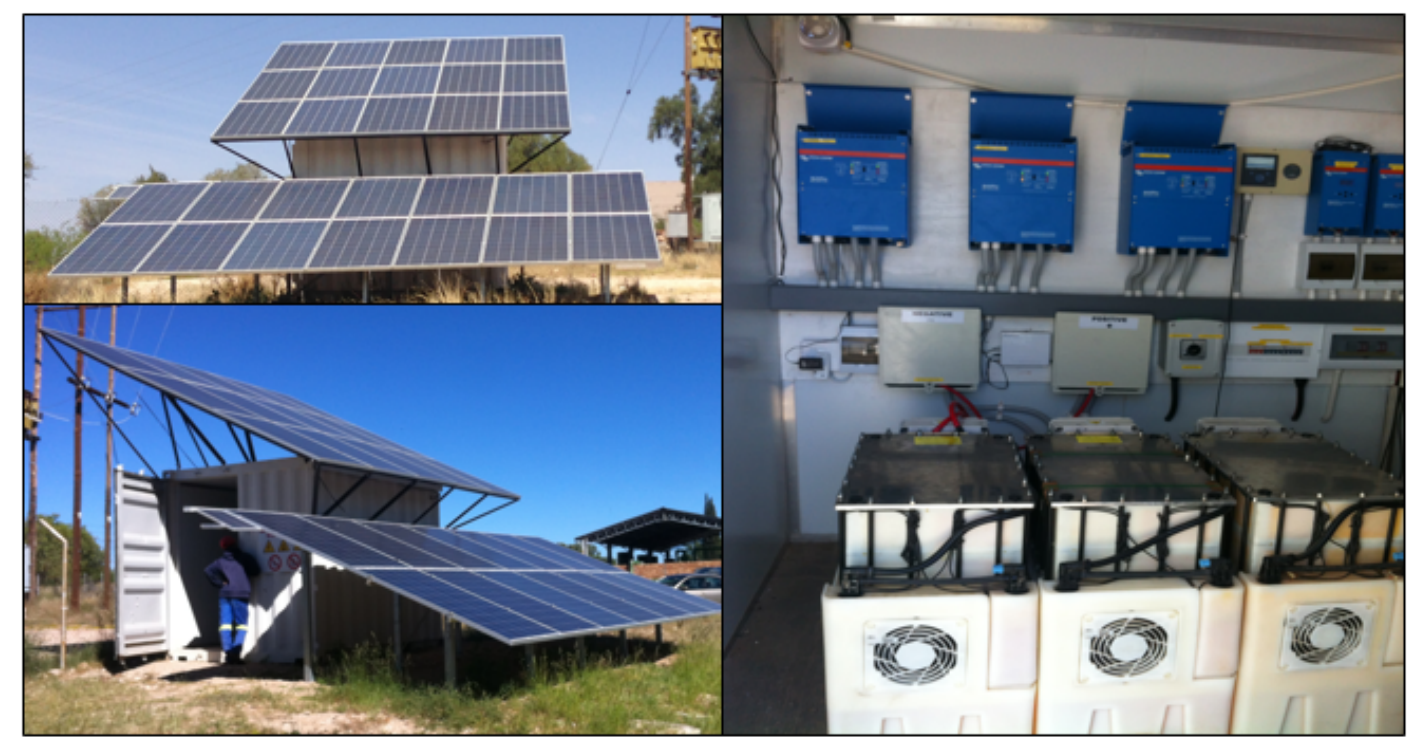

Figure 3. Solar plant.

After initial site selection the final experimental installation was designed. Other than the HK turbines, numerous components were required for operation and maintenance of the turbines. Safety and ease of maintenance is a concern in the area, therefore additional safety measures must be put in place. The canal system is cleaned at specific maintenance intervals and repaired where necessary. The infrastructure components required for the installation of the HK turbines are listed in three sections namely civil components, electro-mechanical components and electrical components:

- $\quad$ Electro-mechanical Components.

1. Smart Hydro Power GmbH (SHP) free stream turbine (Equipped with a $5 \mathrm{~kW}$ generator).

2. Rectifiers.

3. Dump loads.

- $\quad$ Civil Components.

1. Concrete block foundation and cable anchors.

2. Turbine lifting system.

- $\quad$ Electrical Components.

1. Electrical infrastructure.

2. Inverters.

3. Flow meter.

4. Level sensors.

The design considerations during the final component selection and integration can be seen in Table 1.

The turbine selected for the site is shown in Figure 4 and is specifically designed for canal systems. It is placed in the bottom of the canal. System specifications can be seen in Table 2. The turbine is equipped with an underwater generator providing AC power to the system using a permanent magnet generator. To achieve maximum power output from the system a flow velocity of $3.1 \mathrm{~m} / \mathrm{s}$ is required. Estimates of the current velocity in the canal indicated an average speed of flow of about $2 \mathrm{~m} / \mathrm{s}$ and narrowing of the canal to increase power output was considered. 
Table 1. Design Considerations.

\begin{tabular}{|c|c|c|c|c|}
\hline \multicolumn{2}{|c|}{ Component } & Design Options & \multirow{3}{*}{$\begin{array}{l}\text { Design Considerations } \\
\text { SHP was chosen as the turbine supplier. } \\
\text { The freestream was designed specifically } \\
\text { for canal application and fits the operating } \\
\text { range. It is less prone to debris build-up } \\
\text { (due to most debris floating, and grid } \\
\text { deflection device) and better for the } \\
\text { specific application. }\end{array}$} & \multirow{3}{*}{$\begin{array}{l}\text { Final Design } \\
\\
\text { SHP Freestream } \\
\text { turbine. }\end{array}$} \\
\hline \multirow[b]{2}{*}{ 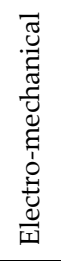 } & \multirow[b]{2}{*}{$\begin{array}{l}\text { Turbine } \\
\text { selection }\end{array}$} & SHP Floating axial flow turbine. & & \\
\hline & & SHP freestream axial flow. & & \\
\hline \multirow{8}{*}{ : } & \multirow[b]{2}{*}{$\begin{array}{l}\text { Anchoring } \\
\text { structure }\end{array}$} & Bottom anchoring onto canal bed. & \multirow{2}{*}{$\begin{array}{l}\text { Initially the Boegoeberg WUA }{ }^{1} \text { requested } \\
\text { no alterations be done on the canal itself. In } \\
\text { addition, an anchoring system outside of } \\
\text { the flow would be simpler for accessibility } \\
\text { purposes. }\end{array}$} & \multirow[b]{2}{*}{ Side Anchoring. } \\
\hline & & $\begin{array}{l}\text { Side anchoring with concrete } \\
\text { anchor blocks. }\end{array}$ & & \\
\hline & \multirow{3}{*}{$\begin{array}{l}\text { Lifting } \\
\text { system }\end{array}$} & Gantry permanent structure. & $\begin{array}{l}\text { Extremely large cost due to large width of } \\
\text { canal. }\end{array}$ & \multirow{3}{*}{ Portable crane. } \\
\hline & & Gantry on rails over all turbines. & $\begin{array}{l}\text { Extremely expensive and would require } \\
\text { only straight level sections (existing site } \\
\text { has a bend). }\end{array}$ & \\
\hline & & Portable crane. & $\begin{array}{l}\text { Second hand crawler crane available at low } \\
\text { cost, single crane can be used for all } \\
\text { turbines (for future installations). }\end{array}$ & \\
\hline & \multirow{3}{*}{$\begin{array}{l}\text { Turbine } \\
\text { placement } \\
\text { (multiple } \\
\text { turbines) }\end{array}$} & $\begin{array}{l}\text { Centre placement (one behind the } \\
\text { other at specific spacing). }\end{array}$ & Fastest velocity in center section of canal. & \multirow{3}{*}{$\begin{array}{l}\text { Center placement } \\
\text { with adjacent } \\
\text { turbines } \\
\text { (depending on } \\
\text { upstream effect). }\end{array}$} \\
\hline & & $\begin{array}{l}\text { Staggered placement (staggered } \\
\text { behind each other). }\end{array}$ & $\begin{array}{l}\text { Staggered placement could result in less } \\
\text { interference between turbines and could } \\
\text { allow closer placement. }\end{array}$ & \\
\hline & & $\begin{array}{l}\text { Adjacent placement (multiple } \\
\text { turbine in single cross-section). }\end{array}$ & $\begin{array}{l}\text { Recommended by supplier, increasing the } \\
\text { Betz limit. }\end{array}$ & \\
\hline \multirow{4}{*}{ 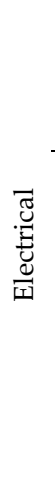 } & \multirow{2}{*}{ Flow meter } & $\begin{array}{l}\text { Doppler velocity sensor and } \\
\text { ultra-sonic level sensor. }\end{array}$ & $\begin{array}{l}\text { Velocity sensor is placed on the canal bed, } \\
\text { with level sensor over the canal wall. }\end{array}$ & \multirow{2}{*}{$\begin{array}{l}\text { Due to theft } \\
\text { resistance the } \\
\text { doppler sensor } \\
\text { was selected. }\end{array}$} \\
\hline & & "Microflow" radar sensor. & $\begin{array}{l}\text { Placed over the canal wall, resulting in } \\
\text { large device sensitive to movement. }\end{array}$ & \\
\hline & \multirow{2}{*}{$\begin{array}{l}\text { Electrical } \\
\text { distribution }\end{array}$} & Stand-alone system. & $\begin{array}{l}\text { Require back-up storage and } \\
\text { self-synchronization. Also a change over } \\
\text { switch from micro-grid mode to municipal } \\
\text { grid mode required when supply is } \\
\text { insufficient. }\end{array}$ & \multirow{2}{*}{$\begin{array}{l}\text { For the purpose } \\
\text { of simplicity, a } \\
\text { grid-tied system } \\
\text { was selected. }\end{array}$} \\
\hline & & Grid-tied system. & $\begin{array}{l}\text { Allows possible integration of the HK } \\
\text { plant with the existing grid and } \\
\text { synchronized with the solar plant when } \\
\text { the grid is off. }\end{array}$ & \\
\hline
\end{tabular}

${ }^{1}$ WUA-Water User Association: A WUA is a statutory body established by the Minister of DWS The main function of a WUA is to ensure fair and reliable water supply to its members, who are mostly irrigation or livestock farmers.

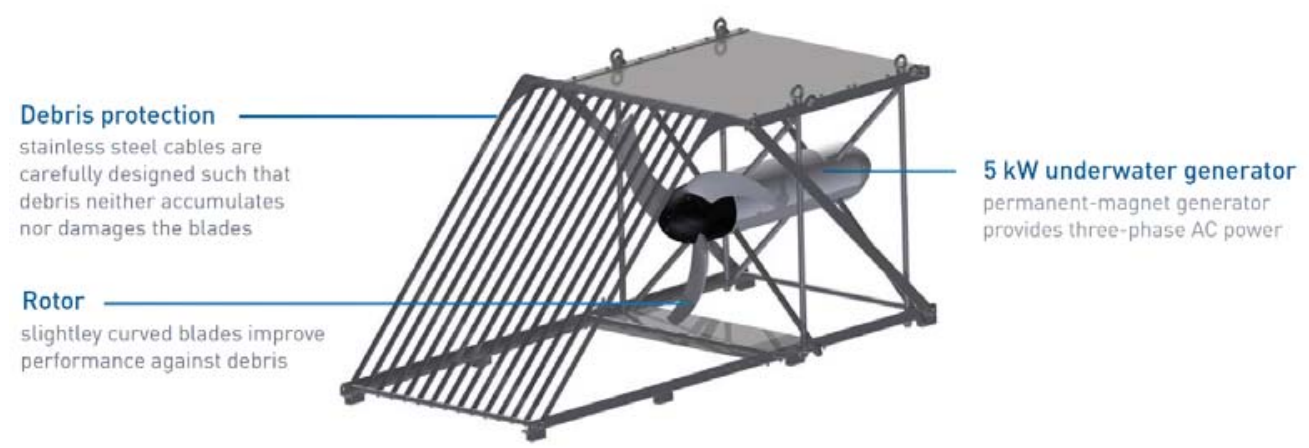

Figure 4. Kinetic turbine for deployment in canal (SHP SMART free stream turbine) [6]. 
Table 2. Turbine specifications [6].

\begin{tabular}{|c|c|c|c|}
\hline \multicolumn{3}{|c|}{ Output (W) } & $250-5000$ \\
\hline \multirow{3}{*}{\multicolumn{2}{|c|}{ Dimensions }} & length $(\mathrm{mm})$ & 2640 \\
\hline & & width (mm) & 1120 \\
\hline & & height (mm) & 1120 \\
\hline \multicolumn{3}{|c|}{ Rotational speed (rpm) } & $90-230$ \\
\hline \multicolumn{3}{|c|}{ Weight (kg) } & 300 \\
\hline \multicolumn{3}{|c|}{ Number of rotor blades } & 3 \\
\hline \multicolumn{3}{|c|}{ Rotor diameter (mm) } & 1000 \\
\hline
\end{tabular}

A turbine was installed between a set of guide plates used to narrow the canal section and test influences of this installation on the canal system before the permanent installation is completed. This setup can be seen in Figure 5. Level sensors where placed at the installation site and at a designated point upstream of the installation. A flow meter was also placed in the straight upstream section, to allow monitoring of the site conditions during testing.

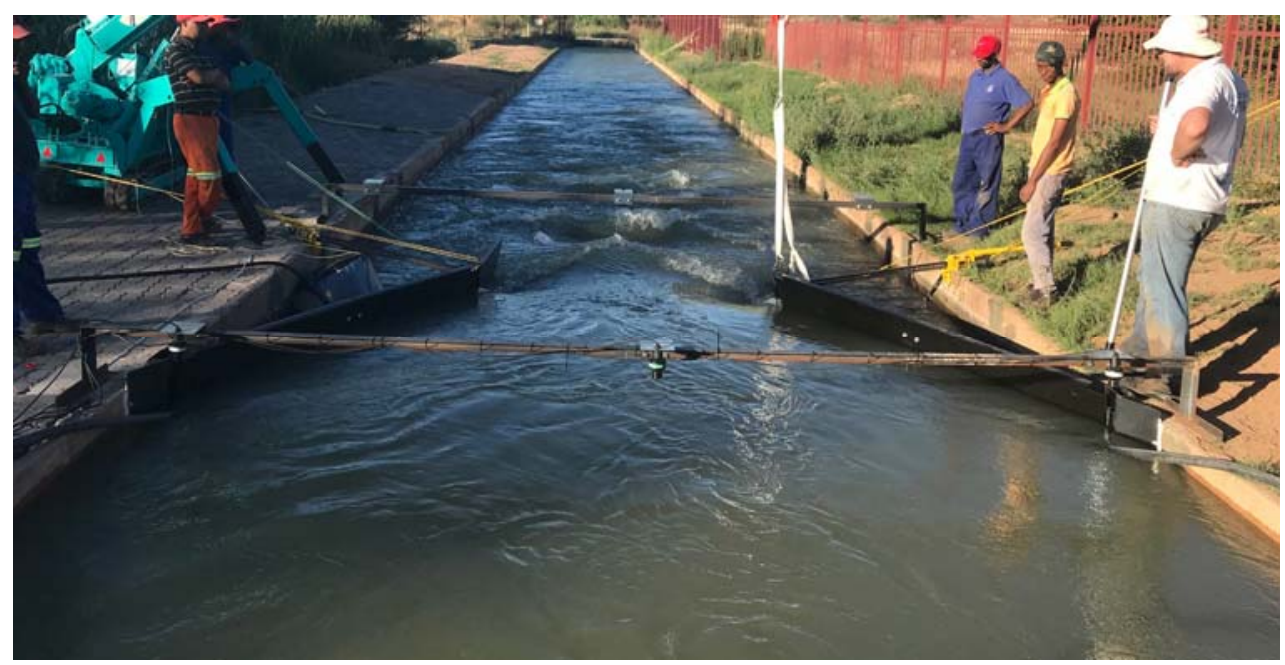

Figure 5. Turbine test installation.

Analysis of the operation of the system proved that a manageable damming effect upstream (by both numerical analysis and field tests) was obtained. The maximum damming occurs just upstream of the installation and falls within the freeboard available (even during full turbine blockage).

The narrowing of the canal by means of guide plates, placed at 21 degrees to the horizontal (typical venturi angle [7]) proved to increase the power output significantly. The cross section was reduced by $50 \%$ and resulted in a doubled velocity, and thereby increasing the power output exponentially.

\section{Discussion}

The implementation of the system was analyzed on a technical, practical, environmental and social perspective. The testing setup of the first HK installation in South Africa should serve as an indication of the effects of such a technology in the typical conditions found on the canal systems running through a vast portion of the country.

The test installation proved to have manageable upstream damming levels and no significant effect on water supply (functioning of the canal). The narrowing of the cross-sectional area proved to enhance the output and aid in utilizing low flow conditions. In addition, the HK installation works in conjunction with the solar plant assisting in reducing the electricity demand for the operation of the WTW.

The installation confirmed to have no significant negative influence on the environment and the production of "clean" renewable energy rather than use of the largely fossil-fuel driven current 
electricity supply far outweighs any minor environmental impacts which may have been missed. An analysis of the environmental influences of the HK installation proved the following:

- No fish life deterioration, due to the canal inlet grid blocking most of the riverine fish population, except for smaller species, which generally are not affected by the spinning blades.

- No habitat destruction caused through the use of man-made canal systems (artificial waterways) rather than riverine applications.

- No sediment disruption of the surrounding area from installation as the canal is concrete lined and the canal sides were used for fastening.

- No altering, impeding or diverting of waterways was done during installation and no major damming caused (which could have resulted in flooding).

- No toxic release of any chemicals (no anti-biofouling, hydraulic fluids etc. used)

- No loud noise from the turbines (no noise pollution) during operation.

The social aspects of the project remain one of the most important factors of this renewable energy development, especially in developing countries where funded projects such as this aid poverty-stricken areas where the majority of the population is not able to afford basic electricity needs. During this specific project the social impacts were observed as shown in Table 3. An overall social analysis proved the positive factors outweigh negative factors which can mostly be solved with small redesigns in the system and theft prevention measures.

The objective of these small-scale HK schemes is to develop a system which poor municipalities could use as a sustainable, cheaper source of electricity with low operating and maintenance costs. If optimal sections in the canal are selected where HK units can produce around $4 \mathrm{~kW}$ each. This would provide the municipality with around $31,140 \mathrm{kWh}$ per annum per turbine (when considering an average of 324 active days), with several of these systems installed and minimal initial and running costs, these systems could potentially save the municipalities on operational expenses, especially during peak periods.

Table 3. HK installation social factors.

\begin{tabular}{|c|c|}
\hline Positive Factors & Negative Factors \\
\hline $\begin{array}{l}\text { The use of local labour for project development allowed an income } \\
\text { for unemployed locals and also a sense of pride and protectiveness } \\
\text { of the installation from the locals in the small community. } \\
\text { The system usually requires little maintenance and allows a } \\
\text { constant supply of electricity through the majority of the year, } \\
\text { aiding the poor municipality financially. } \\
\text { The project functions as a pilot of possible renewable electricity } \\
\text { technologies which could promote the market for HK systems in } \\
\text { South Africa. } \\
\text { Benefits to the !Kheis Municipality would include reducing their } \\
\text { reliance on the national power grid, as well as reducing their } \\
\text { electricity costs and thus mitigating their risk of not being able to } \\
\text { supply water to their communities. }\end{array}$ & $\begin{array}{l}\text { The HK devices are a risk to } \\
\text { children swimming in the canals } \\
\text { (sharp fast flowing propeller blades } \\
\text { could result in injury). } \\
\text { The largely poor area results in } \\
\text { potential theft of components } \\
\text { during canal maintenance periods. } \\
\text { Higher maintenance may be } \\
\text { required due to debris. }\end{array}$ \\
\hline
\end{tabular}

The implementation of small-hydropower systems has been recommended by many international organizations such as the World Bank and United Nations Industrial Development, with proof of the start-up costs of small hydropower systems being almost half that of wind and solar where potential is available [8]. This alternative power source could aid in overcoming the lack of power supply to required areas and lighten financial burdens (in terms of electricity costs). Installation of these units not only supports sustainable development but promotes innovative research which is an important step in forming a stronger self-sustaining economy.

A few aspects of importance were found to be evident during the installation and should be carefully considered in future studies: 
- Procedures and costs involved in the legislative process (factoring in delays) should not be underestimated and considered strongly in the prefeasibility study.

- The appropriate selection of a technology for implementations remains a crucial aspect of consideration, the cross-sectional area and dominant flow conditions should be ascertained and HK technology selected accordingly.

- Theft, vandalism and maintenance proves to be major social issues of consideration in South Africa, and these matters should be dealt with during each development phase and premeditated during the implementation design.

\section{Conclusions}

A large network of canal systems exists in South Africa, most of which are used for conveyance of irrigation water. These largely lie in non-electrified rural areas, resulting in an untapped renewable energy source which could be used to benefit these areas. HK applications in canal systems, rather than riverine flow, where water levels and velocities vary between seasons, allow a more uniform controlled environment where a constant flow pattern is exhibited throughout most of the year, resulting in a more constant power output. Although these canals are prone to interval shut off times, this can be planned for and remains a controlled environment.

A negative factor lies in the lack of high velocities, as was found in this project. However, this can be avoided with the careful selection of steep or narrowed sections where a higher velocity is present. Additionally, the option of "low flow" HK turbines exist, which are designed for lower velocity applications.

Not only does HK hydropower development allow provision of a more sustainable energy source for the local authority, but also the use of small HK schemes to assist in water management in the form of electrified metering in off-grid areas etc. which allows better control/management of water sources (which remains a major problem in South Africa). Additionally, irrigation by its nature, is concentrated in rural areas not connected to the grid thereby opening an opportunity for rural electrification.

Acknowledgments: This research was made possible by the financial support of the South Africa Department of Science and technology and Water Research Commission. The work was supported by the University of Pretoria, and authorized by the !Kheis Municipality. Additionally, the project was completed as a pilot under the DWS General notice: Draft Policy on Sustainable Hydropower Generation.

\section{References}

1. MEAAI. Energy Report 2011; Ministry of Economic Affairs, Agriculture and Innovation: Den Haag, The Netherlands, 2011.

2. Koko, P.S.; Kusakana, K. Techno-Economic Analysis of an Off-Grid Micro-Hydrokinetic River System as a Remote Rural Electrification Option; Free State CUT: Bloemfontein, South Africa, 2014.

3. White, J. Viability of Small Scale Hydropower in South Africa; University of Cape Town: Cape Town, South Africa, 2011.

4. Van Vuuren, S.J.; Blersch, C.L.; van Dijk, M. Modelling the feasibility of retrofitting hydropower to existing South African dams. Water SA 2011, 37, 679-692.

5. Kartezhnikova, M.; Ravens, T.M. Hydraulic impacts of hydrokinetic devices. Renew. Energy 2014, 66, 425-432.

6. SHP. Installer Training Manual; Smart Hydropower GmbH: Feldafing, Germany, 2017.

7. Reader-Harris, M.J.; Brunton, W.C.; Gibson, J.J.; Hodges, D.; Nicholson, I.G. Discharge coefficients of Venturi tubes with standard and non-standard convergent angles. Flow Meas. Instrum. 2001, 12, 135-145.

8. Elbatran, A.H.; Yaakob, O.B.; Yasser, M.A.; Shabara, H.M. Operation, performance and economic analysis of low head micro-hydropower turbines for rural and remote areas: A review. Renew. Sustain. Energy Rev. $2015,43,40-50$.

(C) 2018 by the authors. Licensee MDPI, Basel, Switzerland. This article is an open access article distributed under the terms and conditions of the Creative Commons Attribution (CC BY) license (http://creativecommons.org/licenses/by/4.0/). 